\title{
Simulation of Stage and Hydrologic Budget for Shell Lake, Washburn County, Wisconsin
}

Water-Resources Investigations Report 99-4209

Prepared in cooperation with the

City of Shell Lake, Wisconsin, and the Wisconsin Department of Natural Resources 



\section{Simulation of Stage and Hydrologic Budget for Shell Lake, Washburn County, Wisconsin}

By J.T. Krohelski, D.T. Feinstein, and B.N. Lenz

U.S. GEOLOGICAL SURVEY

Water-Resources Investigations Report 99-4209

Prepared in cooperation with the

CITY OF SHELL LAKE, WISCONSIN

WISCONSIN DEPARTMENT OF NATURAL RESOURCES

Middleton, Wisconsin

1999

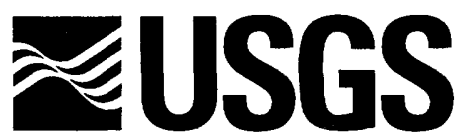




\title{
U.S. DEPARTMENT OF THE INTERIOR BRUCE BABBITT, Secretary
}

\author{
U.S. GEOLOGICAL SURVEY \\ Charles G. Groat, Director
}

The use of firm, trade, and brand names in this report is for identification purposes only and does not constitute endorsement by the U.S. Geological Survey.

For additional information write to:

District Chief

U.S. Geological Survey

8505 Research Way

Middleton, WI 53562-3586
Copies of this report can be purchased from:

U.S. Geological Survey

Branch of Information Services

Box 25286

Denver, CO 80225-0286 


\section{CONTENTS}

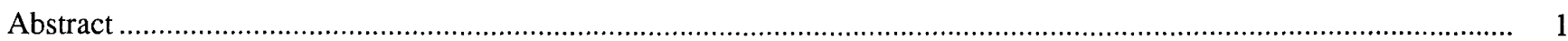

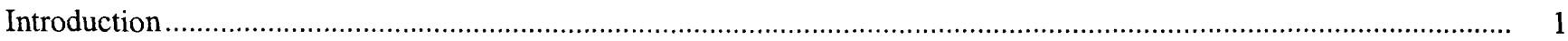

Purpose and scope

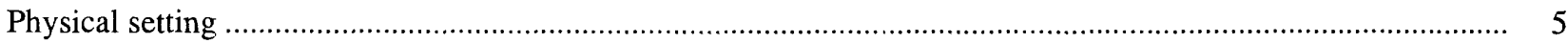

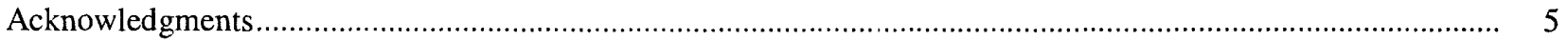

Determination of hydrologic-budget components and model coefficients ……................................................... 5

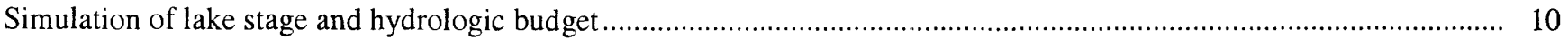

Model calibration

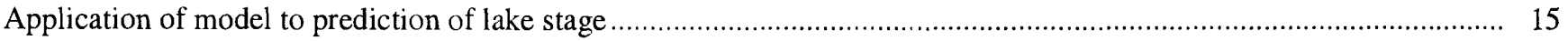

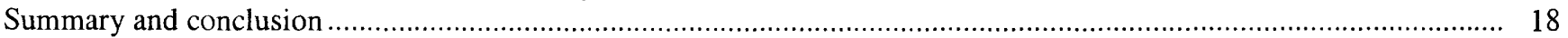

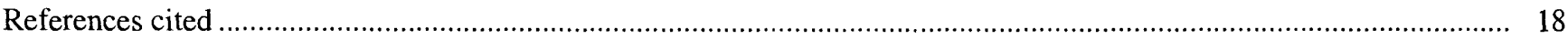

Appendix. Fortran program code used to simulate changes in stage of Shell Lake caused by variations in hydrologicbudget components

\section{FIGURES}

1. Map showing location of Shell Lake, gaging station, surface water basin, and tributary streams and wetlands.....

2-3. Graphs showing:

2. Recorded stages for Shell Lake at Shell Lake, Wis. (1936-98)

3. Cumulative departure from average stage of Shell Lake, precipitation and water table, 1936-96

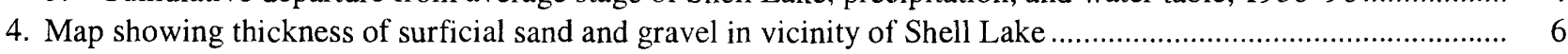

5-6. Graphs showing:

5. Spouner Experimental Farm precipitation (1947-97) with the five-year moving average

6. Difference in precipitation from the Spooner Experimental Farm and pan evaporation (multiplied by 0.8) from the Marshfield Experimental Farm (1949-96) and Minocqua Airport (1997-98) with the annual average and the five-year moving average

9. Chart showing program steps in hydrologic-budget model of Shell Lake, Wis.
7. Maps showing gradients between Shell Lake and the shallow ground-water system for August 1998 and March 1999
8. Graph showing daily stage of Shell Lake, shallow ground-water level, and precipitation recorded at the USGS

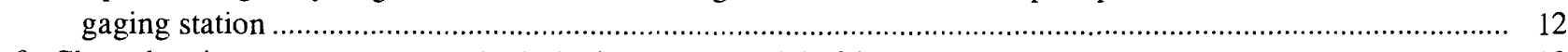

10-11. Graphs showing:

10. Simulated and measured stage of Shell Lake (1948-98).

11. Calibrated-model and predicted lakes stages and the difference between calibrated and predicted lake stages 
CONVERSION FACTORS, VERTICAL DATUM, AND ABBREVIATED WATER-QUALITY UNITS

\begin{tabular}{|c|c|c|}
\hline Multiply & By & To Obtain \\
\hline \multicolumn{3}{|c|}{ Length } \\
\hline $\begin{array}{r}\text { inch (in.) } \\
\text { foot (ft) } \\
\text { mile (mi) }\end{array}$ & $\begin{array}{l}25.4 \\
0.3048 \\
1.609\end{array}$ & $\begin{array}{l}\text { millimeter } \\
\text { meter } \\
\text { kilometer }\end{array}$ \\
\hline \multicolumn{3}{|c|}{ Area } \\
\hline $\begin{array}{r}\text { acre }(\mathrm{A}) \\
\text { square foot }\left(\mathrm{ft}^{2}\right) \\
\text { square mile }\left(\mathrm{mi}^{2}\right)\end{array}$ & $\begin{array}{l}0.4047 \\
0.09290 \\
2.590\end{array}$ & $\begin{array}{l}\text { hectare } \\
\text { square meter } \\
\text { square kilometer }\end{array}$ \\
\hline \multicolumn{3}{|c|}{ Volume } \\
\hline cubic foot $\left(\mathrm{ft}^{3}\right)$ & 0.4047 & hectare \\
\hline \multicolumn{3}{|c|}{ Hydraulic conductivity* } \\
\hline foot per day $(\mathrm{ft} / \mathrm{d})$ & 0.3048 & meter per day \\
\hline
\end{tabular}

Sea level: In this report, "sea level" refers to the National Geodetic Vertical Datum of 1929 (NGVD of 1929)—a geodetic datum derived from a general adjustment of the first-order level nets of both the United States and Canada, formerly called Sea Level Datum of 1929.

*Hydraulic conductivity: The standard unit for hydraulic conductivity is cubic foot per day per square foot of aquifer cross-sectional area $\left(\mathrm{ft}^{3} / \mathrm{d}\right) / \mathrm{ft}^{3}$. In this report, the mathematically reduced form, feet per day $(\mathrm{ft} / \mathrm{d})$, is used for convenience.

Other abbreviations:

gpm gallons per minute

cfs cubic feet per second

The stratigraphic nomenclature used in this report is that of the Wisconsin Geological and Natural History Survey and does not necessarily follow usage of the U.S. Geological Survey. 


\title{
Simulation of Stage and Hydrologic Budget for Shell Lake, Washburn County, Wisconsin
}

\author{
By J.T. Krohelski, D.T. Feinstein, and B.N. Lenz
}

\section{Abstract}

A model that simulates lake stage was developed to test the current understanding of the hydrology of Shell Lake, Wisconsin and to provide a tool for predicting the effects of withdrawing lake water on future lake stages. The model code is written in Fortran and simulates daily lake stage by summing estimates of hydrologic-budget components-precipitation falling on the lake surface, water evaporating from the lake surface, runoff (consisting of overland flow to the lake and intermittent streams flowing into the lake), and groundwater flow out of the lake.

The model was calibrated to intermittent lake stage measurements for the period 1948-98. The hydrologic budget model was coupled to UCODE, a parameter estimation model, to aid in estimating runoff coefficients. Trends in stage simulated by the calibrated model compare reasonably well with historical stage trends. The root mean square of the differences of simulated and measured daily lake stage for the period $1948-98$ is 0.54 foot.

Predictive simulations indicate that withdrawing lake water is an effective way of reducing lake stage. Several years of pumping for at least 200 days per year at rates of 1,000 to 2,000 gallons per minute would have been required to reduce 1990's high stages by about one foot.

\section{INTRODUCTION}

Shell Lake, located in Washburn County in northwestern Wisconsin, lies completely within the City of Shell Lake (fig. 1). The City, which is responsible for shoreline zoning, has been concerned over the recent flooding of several near-shore residences. A committee, appointed by the City to investigate ways to mitigate the flooding, has considered withdrawing lake water during high stage periods. The committee agreed that before decisions to mitigate the flooding can be made, a better understanding of the hydrology of the lake and the longterm effect of withdrawing lake water on lake stage is required. To meet this need, the U.S. Geological Survey (USGS) in cooperation with the City of Shell Lake and the Wisconsin Department of Natural Resources (WDNR), initiated a study of Shell Lake in January of 1998.

Simple models of lake hydrology can often be developed inexpensively and used to simulate lakestage fluctuations caused by variation in hydrologicbudget components or withdrawal or addition of water. A model that accurately simulates lake stage over a decade or more increases confidence that the lake hydrology is understood. This method has been used previously to predict changes in lake stage caused by aquifer dewatering (Krug and others, 1987) and withdrawal of lake water (Krohelski and Batten, 1995). Further development of this method will lead to more accurate models and help Lake Districts in Wisconsin and water-resource planners to understand the hydrology of lakes and to effectively manage water resources.

Shell Lake stage data, collected since 1936, indicate a ten- to fifteen-year cycle between low and high lake stages (fig. 2). For the period of record, the average lake stage is $1,219 \mathrm{ft}$ above sea level, the minimum stage is $1,215 \mathrm{ft}$ above sea level (on November 28 , 1949 ) and the maximum is $1,222 \mathrm{ft}$ above sea level (on June 24, 1996). There is historical evidence that the maximum lake stage could be as high as $1,229 \mathrm{ft}$ above sea level as documented by a high-water mark from about 1900 (Douglas Joseph, Wisconsin Department of Natural Resources, written commun.,1998).

A comparison of the cumulative departure from average precipitation (from Spooner, Wis.), water-table elevation (from an observation well near Hayward, Wis.), and lake stage indicates that the lake stage is influenced by the relation among these natural hydrologic budget components, rather than, for example, by the effects of outside influences such as land-use changes in the lake's watershed (fig. 3). Generally, as precipitation increases or decreases there is an accom- 


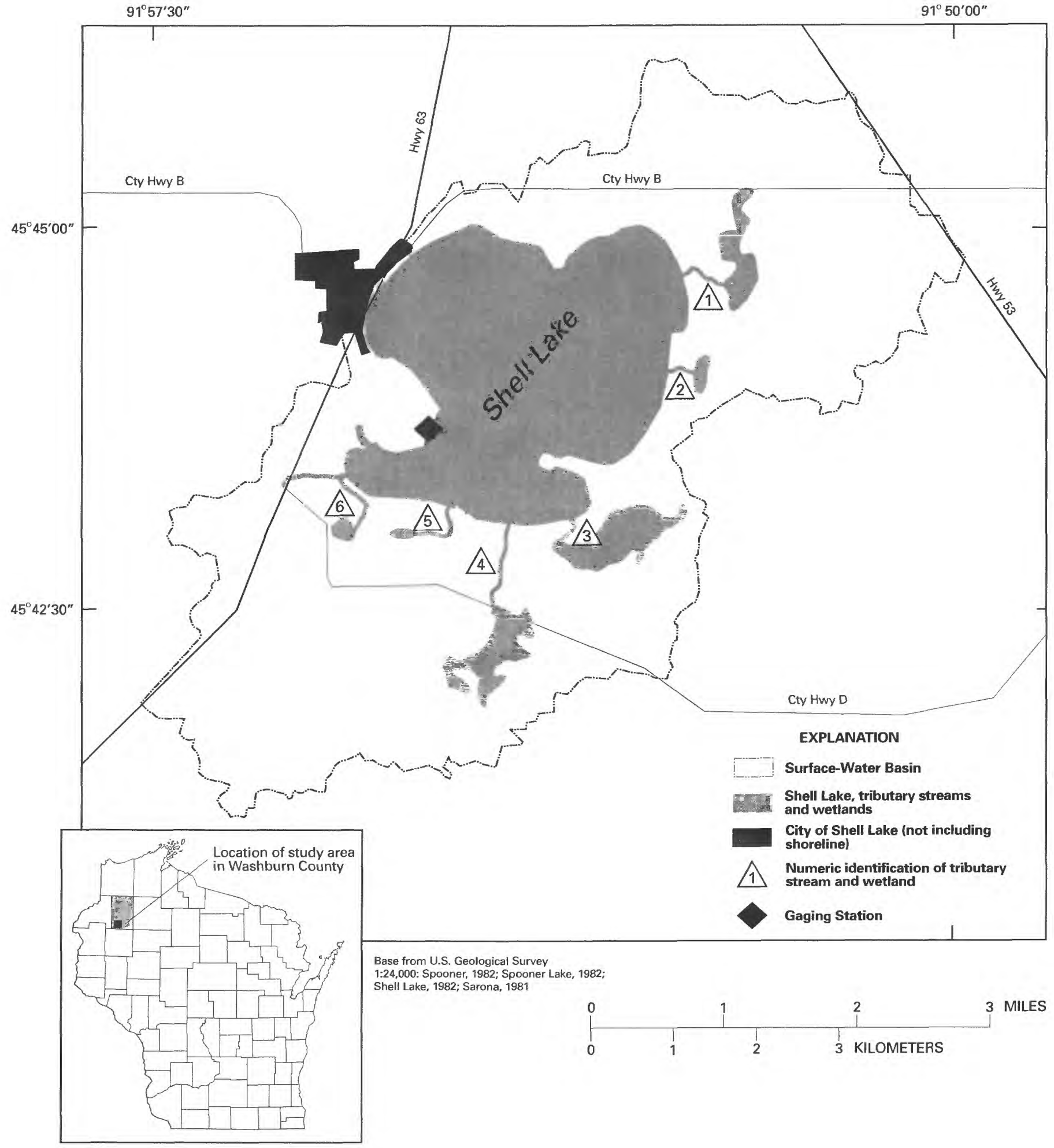

Figure 1. Location of Shell Lake, gaging station, surface water basin, and tributary streams and wetlands. 


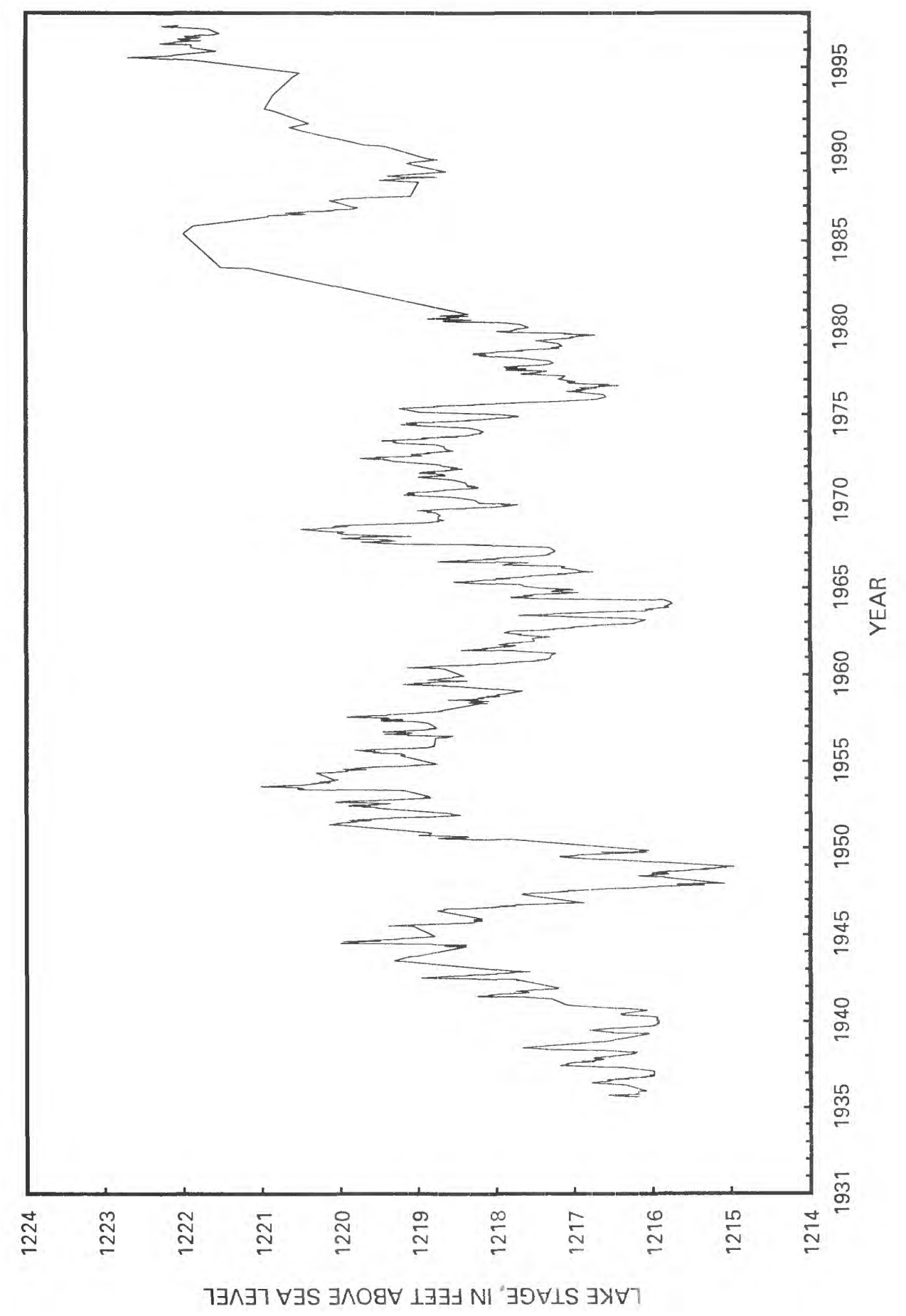

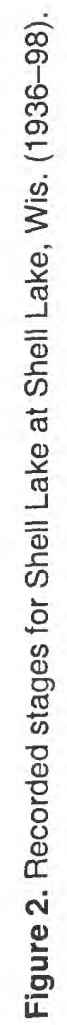




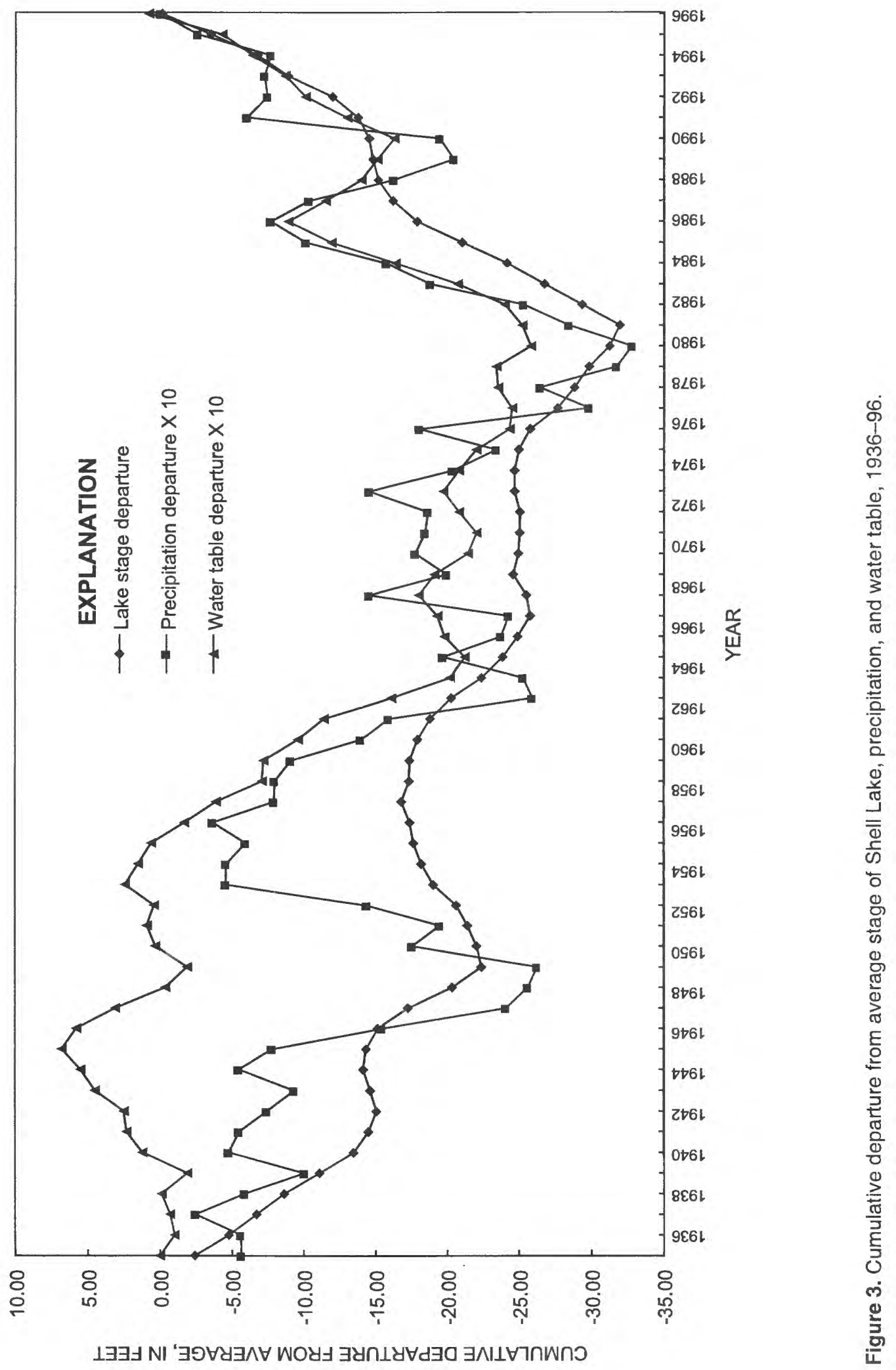


panying response in the water table and lake stage. Lake-stage departures increase substantially more than the water-table departures during periods of high precipitation (Note that the water-table departures are multiplied by 10 in fig. 3 ). The correlation between precipitation and lake stage underscores the importance of input from surface water to the lake, either from intermittent tributary streams or overland flow.

\section{Purpose and Scope}

This report describes the hydrology of Shell Lake and provides a tool (water-budget model) to predict the effects of withdrawing lake water on future lake stages.

In addition to lake stage and climate data. driller's construction reports for wells near the lake, a geologic $\log$ for the Shell Lake municipal well, and two previous studies provided information for this study. During an earlier study, nine piezometer nests (a group wells finished at varying depths with short screens) were installed (Wisconsin Department of Natural Resources, 1982). Although the piezometers were abandoned in 1983, logs of these piezometers describe the geologic materials to a depth of about $50 \mathrm{ft}$ adjacent to the lake, and water-level data from these wells indicate gradients and direction of ground-water flow. The U.S. Army Corps of Enginecrs (1988) also conducted a feasibility study to determine how best to withdraw water from the lake.

Long-term and short-term intensive monitoring of precipitation, lake stage, and ground water was used to describe the hydrology of Shell Lake. Long-term records of lake stage measured by the USGS and the City of Shell Lake were obtained from the USGS database and the City. Precipitation and evaporation records were obtained from weather stations nearest to Shell Lake (Spooner, Marshfield, and Minocqua, Wis., not shown). A gaging station, located on the southwest side of the lake, was installed in June 1998 and operated during non-freezing periods (fig. 1). Two surveys using mini-piezometers (small diameter piezometers) installed in the near-shore lakebed were conducted (August 1998 and March 1999) to estimate an average hydraulic gradient. Coefficients were used to estimate runoff to the lake, evaporation from the lake surface, and net ground-water flow from the lake on a daily basis.

A computer model program to simulate changes in lake stage caused by the variation in $h y$ drologic-budget components was developed. The model was calibrated by comparing simulated to measured lake stages for the period 1946-98. The model-calibration process was automated and some coefficients were estimated using UCODE, a parameter estimation model (Poeter and Hill, 1998).

\section{Physical Setting}

Shell Lake's surface area is 2,580 acres (Wisconsin Department of Natural Resources, 1995), which is roughly one-quarter of the area of its surface-water basin (11,390 acres) (fig. 1). Shell Lake is a seepage lake, having no surface outlet but with associated wetlands linked to the lake by intermittent streams. The lake is relatively shallow with a mean depth of $23 \mathrm{ft}$ and a maximum depth of $36 \mathrm{ft}$ (Wisconsin Department of Natural Resources, 1995). The basin containing Shell Lake was formed in part by glacial ice and in part by tunnel channel activity. In general, thin deposits of sand and gravel overlie Copper Falls till (70 percent sand, 20 percent silt, and 10 percent clay) (Mark Johnson, Department of Geology, Gustavus Adolphus College, written commun., 1999). This interpretation is supported by review of approximately 200 driller's construction reports of wells in the vicinity of Shell Lake. Thickness of surficial sand and gravel deposits range from 0 to more than $50 \mathrm{ft}$ and appear to be thickest on the north side of the lake (fig. 4).

\section{Acknowledgments}

Special thanks are extended to Brad Peterson (City of Shell Lake) for measuring lake stage during the 1998-99 winter and to Douglas Joseph (WDNR) for providing initial reconnaissance of the lake and historical information. Paul Juckem (USGS) was responsible for formatting and verifying model input and assisted in preparing the report illustrations.

\section{DETERMINATION OF HYDROLOGIC- BUDGET COMPONENTS AND MODEL COEFFICIENTS}

The hydrologic budget of Shell Lake can be described by the following equation: 


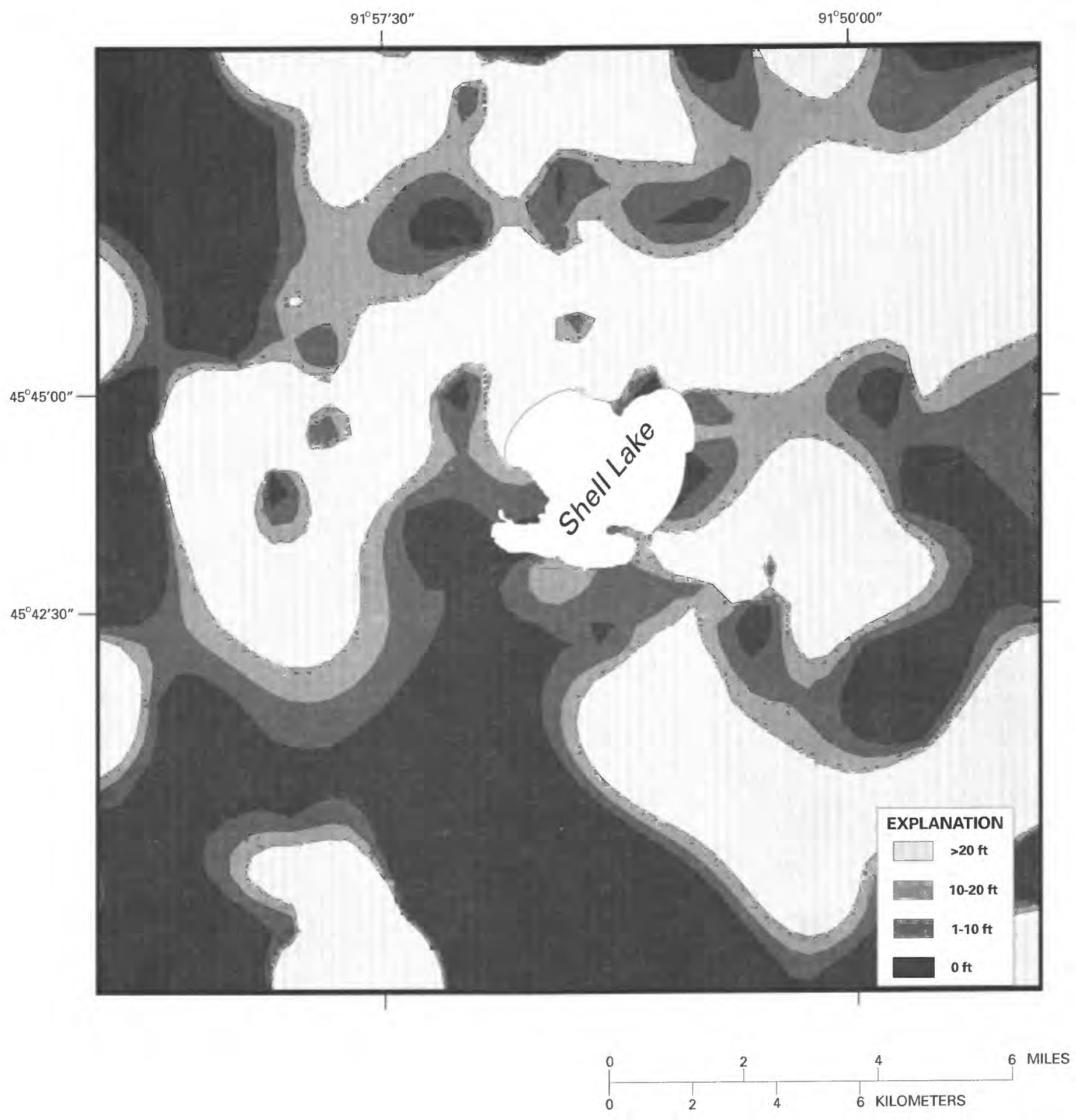

Figure 4. Thickness of surficial sand and gravel in vicinity of Shell Lake. 


$$
\Delta S=\frac{[P+R O-E-G W]}{A(S)}
$$

where

$\Delta S \quad$ is change in lake stage for a given time interval,

$P \quad$ is volume of precipitation falling directly on the lake over the interval,

$R O$ is volume of stream inflow and overland runoff into the lake over the interval,

$E$ is volume of water evaporated from the lake surface over the interval,

$G W$ is volume of net ground-water flow over the interval (positive for outflow, negative for inflow),

$A(S)$ is the lake area for the stage at the beginning of the time interval.

The sum of the hydrologic budget components determines the change in lake stage $(\Delta S)$. If the sum is positive there will be a corresponding increase in lake stage that results in an increase in lake area. The opposite results - the stage and area of the lake decrease--if the sum of the components is negative. A regression equation based on the relation between lake stage and area was developed from an available bathymetric map. The equation was used to determine lake stage from a calculated lake area or to determine lake area from a calculated lake stage.

Lake stage $(S)$ was measured intermittently since August 1936, and continuously during non-freezing periods from May 5, 1998 through fall of 1999, at a gaging station on the southwest side of the lake (fig. 1). During the winter of 1998-99 a local observer measured lake stage intermittently.

Precipitation $(P)$ data were obtained from the Spooner Experimental Farm for the period July 3, 1948 to December 31, 1998. Data from the Shell Lake gaging station were used in place of the Spooner data whenever available. The Spooner Experimental Farm is approximately 5 mi north of Shell Lake. Based on the Spooner Experimental Farm precipitation record, the average precipitation for the period of record is 29.3 in. per year. The maximum was 45.3 in. in 1991 and the minimum was 15.1 in. in 1977 (fig. 5). A five-year moving average of annual precipitation (fig. 5) indicates trends that coincide with the ten to fifteen year high to low cycles in lake stage that are evident in figure 2.

Evaporation $(E)$ from the lake surface was estimated by using pan-evaporation data obtained from the Marshfield Experimental Farm for the period 1948-96 and the Minocqua Airport for the period 1997-98.
Marshfield is approximately $115 \mathrm{mi}$ southeast of Shell Lake and Minocqua is about $132 \mathrm{mi}$ east. The pan-evaporation data were multiplied by 0.80 , a typical lake-pan coefficient for Wisconsin, to estimate evaporation from the lake surface (Wentz and Rose, 1991). The average difference between precipitation and evaporation at Marshfield is 2.31 in. (fig. 6). Even though the distance between Spooner and the Marshfield Experimental Farm is considerable, the difference between precipitation and evaporation at the two sites is in close agreement to values published by Novitzki (1982) for this area of Wisconsin. Data from Minocqua were used because data from Marshfield were not available for 1997-98 during this study. The difference between precipitation at Spooner and evaporation at Minocqua is about 6 in. The five-year moving average of precipitation rninus evaporation indicates a below-average period from 1960 to 1985 , and an above-average period after 1985. The difference between precipitation and evaporation clearly has some relation to the lake stage cycles in figure 2.

Six streams and wetlands are tributary to Shell Lake (fig. 1). Stream conditions were monitored by observation approximately once a month from February 1998 to September 1999. Flow was never observed in tributaries 1 and 2, though evidence of flow was observed after several intense storms in the spring of 1999. Tributaries 3 and 4 generally flowed at about $1 \mathrm{cfs}$ continually throughout the study period with slight increases in flow during rainstorms. During periods of little or no rainfall, tributaries 5 and 6 did not flow; during snowmelt or rainfall events, however, they had the greatest flows of the six tributaries. The highest measured flow in any tributary occurred as a result of snowmelt and rainfall runoff on February 28, 1998 in tributaries 5 and 6 , which had flows of 7 and $15 \mathrm{cfs}$, respectively.

Runoff $(R O)$ from the tributaries and overland flow into the lake was estimated by first multiplying the lake surface-water basin area (surface-water basin area minus the lake area) by the three-day moving average for precipitation, and then multiplying that product by a runoff coefficient. Coefficients for six seasonal runoff periods extending from March 16 to November 30 were estimated using UCODE (Poeter and Hill, 1998), a parameter estimation model, which is discussed in the following section. Runoff from the basin to the lake during December, January, February, and the first half of March was assumed to be zero because of freezing conditions. 


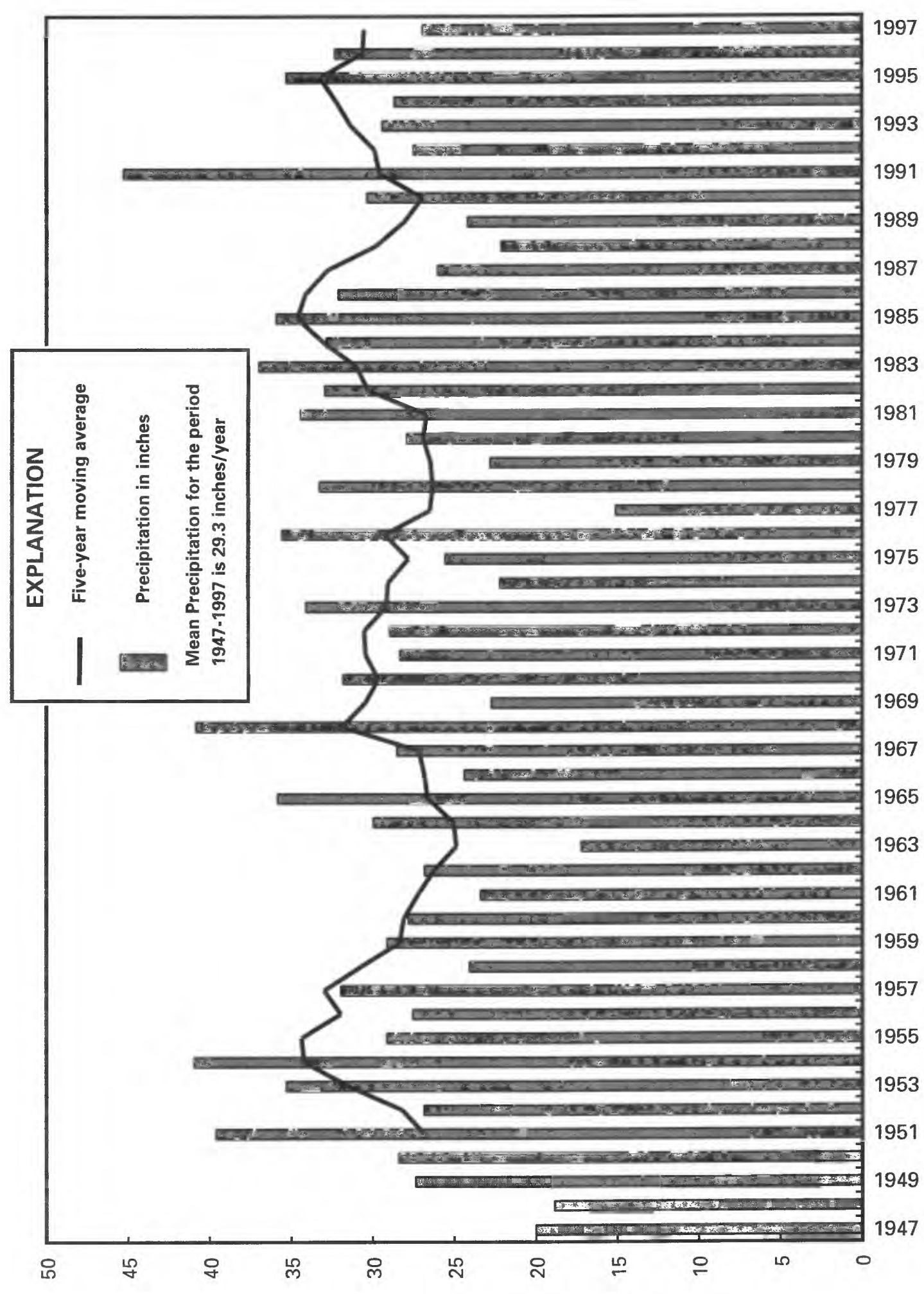

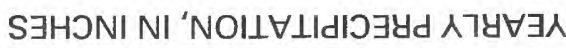




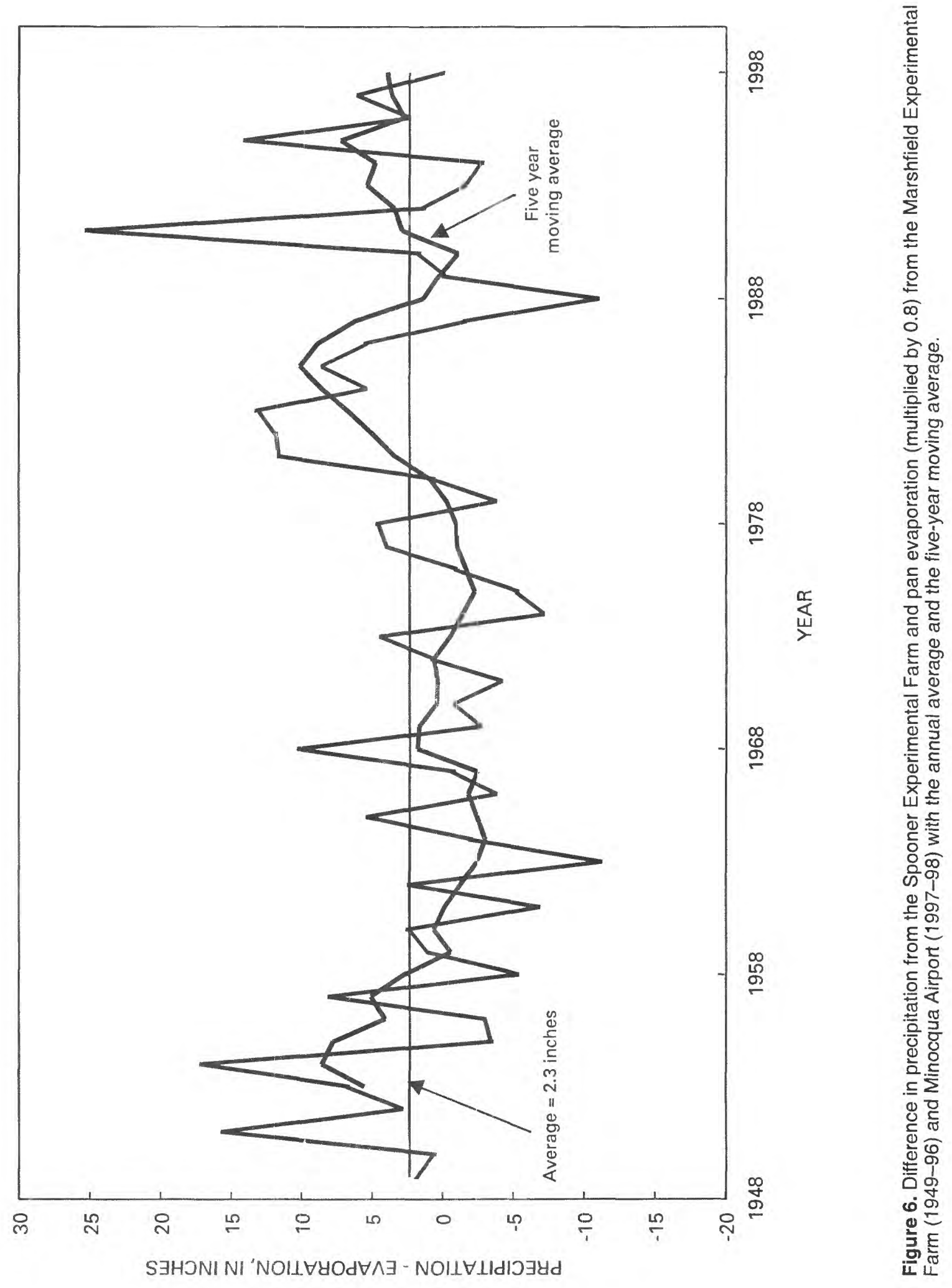


Ground-water inflow and outflow areas were determined by installing a total of 22 piezometers around the lake edge during August 17-21, 1998 and 13 piezometers during March 15-17, 1999. Piezometers were installed along the lake edge because the most seepage occurs near shore (McBride and Pfannkuch, 1975). Measured ground-water gradients indicate that Shell Lake is generally losing water to the ground-water system (figs. 7a and b). The average gradient for the August 1998 measurement period is -0.21 foot per foot and -0.19 for March 1999 (assuming that dry piezometers have a gradient of -1.0 foot per foot, which is the smallest possible gradient). The average for both periods is -0.20 foot per foot indicating that Shell Lake has a net loss of water to the shallow ground-water system. At times, however, ground water may flow into the lake in some small areas. Examples of these areas are shown by positive gradients in figures $7 \mathrm{a}$ and $\mathrm{b}$, and at the gaging station during periods when the ground-water level measured in the well is greater than the lake level (fig. 8).

Ground-water flow (GW) out of the lake was estimated using Darcy's Law by multiplying daily lake area times an average hydraulic gradient $(-0.20)$ times a hydraulic conductivity. Hydraulic conductivity was estimated as part of the model calibration process discussed in the following section.

\section{SIMULATION OF LAKE STAGE AND HYDROLOGIC BUDGET}

A computer model program to simulate changes in lake stage caused by the variation in hydrologic-budget components was written in Fortran (appendix).

The following assumptions were made to allow the use of available climatological data and to simplify the model:

1. Precipitation and evaporation amounts recorded at nearby weather stations were representative of the amounts at Shell Lake.

2. Seasonal runoff coefficients estimated by use of UCODE are representative for the entire period of record. In addition, runoff from snowmelt is assumed to occur over a one-day period, March 15. The water equivalent of total snowfall from December through March 15 is summed and stored, and the total sum is added to the lake on March 15. The model results are not sensitive to the exact day selected to represent late winter/early spring snowmelt.

3. Hydraulic gradient was constant for the entire simulation period. Hence, the amount of net ground-water flow is proportional to lake area.

The model program calculates daily lake stage. The major program steps are shown in figure 9. The program first reads precipitation and pan-evaporation data for the entire simulated period. Coefficients for runoff and evaporation, surface-water basin area, lake/groundwater gradient, and vertical hydraulic conductivity are initialized and the beginning lake stage is read. Then, from current or beginning daily lake stage, lake area is calculated.

A series of "if statements" are executed in the program to determine the volume of runoff during the current day. Runoff for six periods, winter (December through March 15), early spring (March 16-April), spring (May), summer (June, July, and August), fall (September and October) and late fall (November) have different coefficients. To calculate daily runoff amount, the coefficients are multiplied by the area of the dryland surface-water basin and the three-day moving average for precipitation. For winter, runoff volume is summed and added to the lake on March 15.

After daily runoff is calculated, the amount of ground-water flow is calculated using Darcy's Law. Ground-water flow is calculated by multiplying the gradient by the vertical hydraulic conductivity of the lakebed by the area of the lake. If the previous day lake stage is greater than a prescribed threshold, then the lake is assumed to lap onto the more permeable deposits along its fringe that allow more ground-water outflow. The parameters controlling this "fringe" effect are quantified during the calibration process discussed below.

Finally, the lake stage for the start of the next day is calculated by adding the change in stage due to daily precipitation and runoff, evaporation and ground-water flow. The next daily lake stage is then calculated in the model starting with the calculation of a new lake area.

\section{MODEL CALIBRATION}

The water-budget model was calibrated by varying runoff coefficients and the vertical hydraulic conductivity of the lakebed so that model-calculated daily lake stage closely matched 51 years of intermittent measurements of daily lake stage $(1,387$ lake stage measurements from July 3, 1948 to December 31, 1998). The 

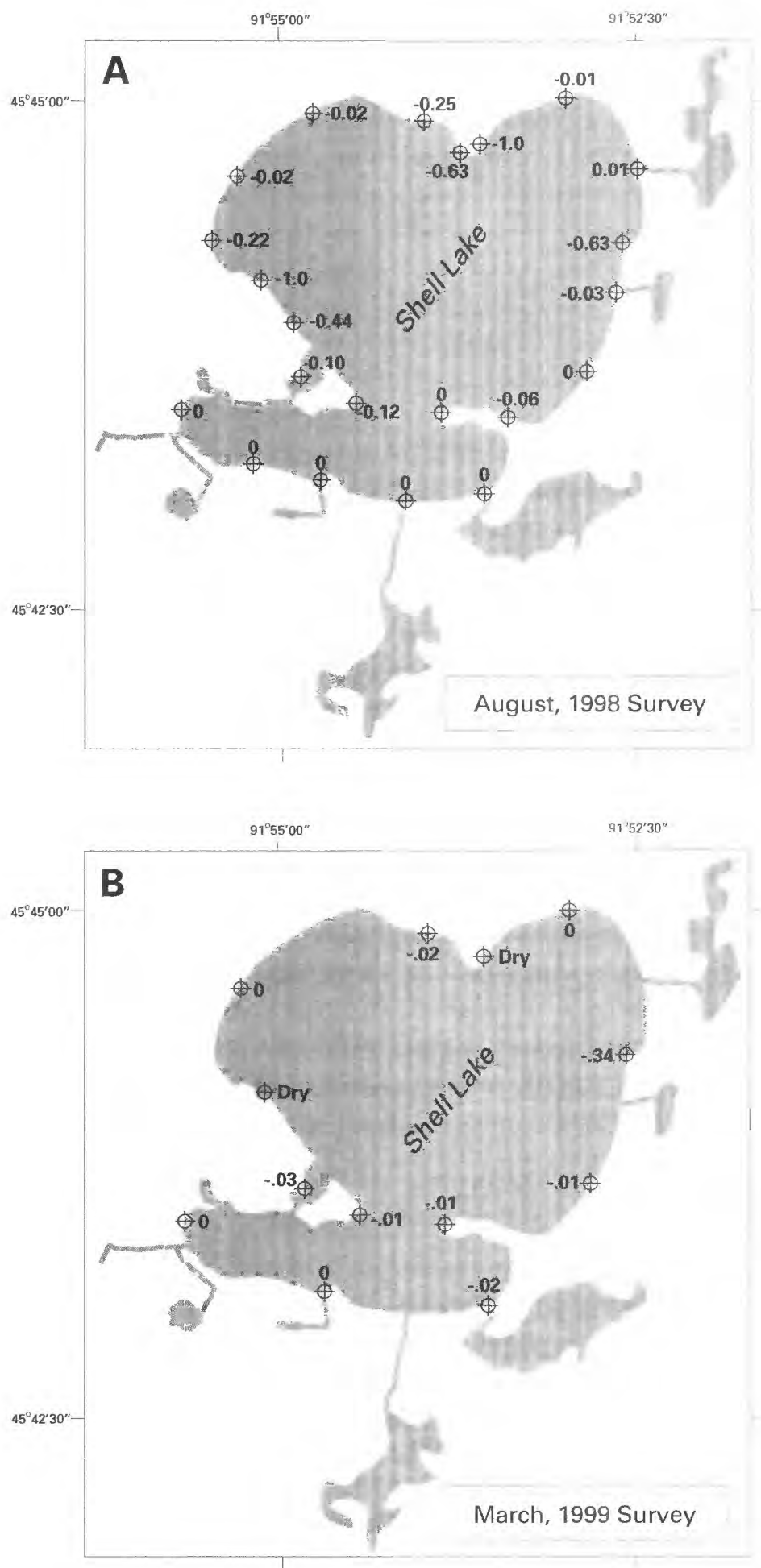

\section{EXPLANATION}

$-.340$

Piezometer location and gradient (negative indicates flow from lake to ground water)

Figure 7. Gradients between Shell Lake and the shallow ground-water system for (A) August 1998 and (B) March 1999 
า $\exists \wedge \exists า \forall \exists S \exists \wedge O 8 \forall \perp \exists \exists \exists N I ' \exists \supset \forall \perp S \exists X \forall 7$

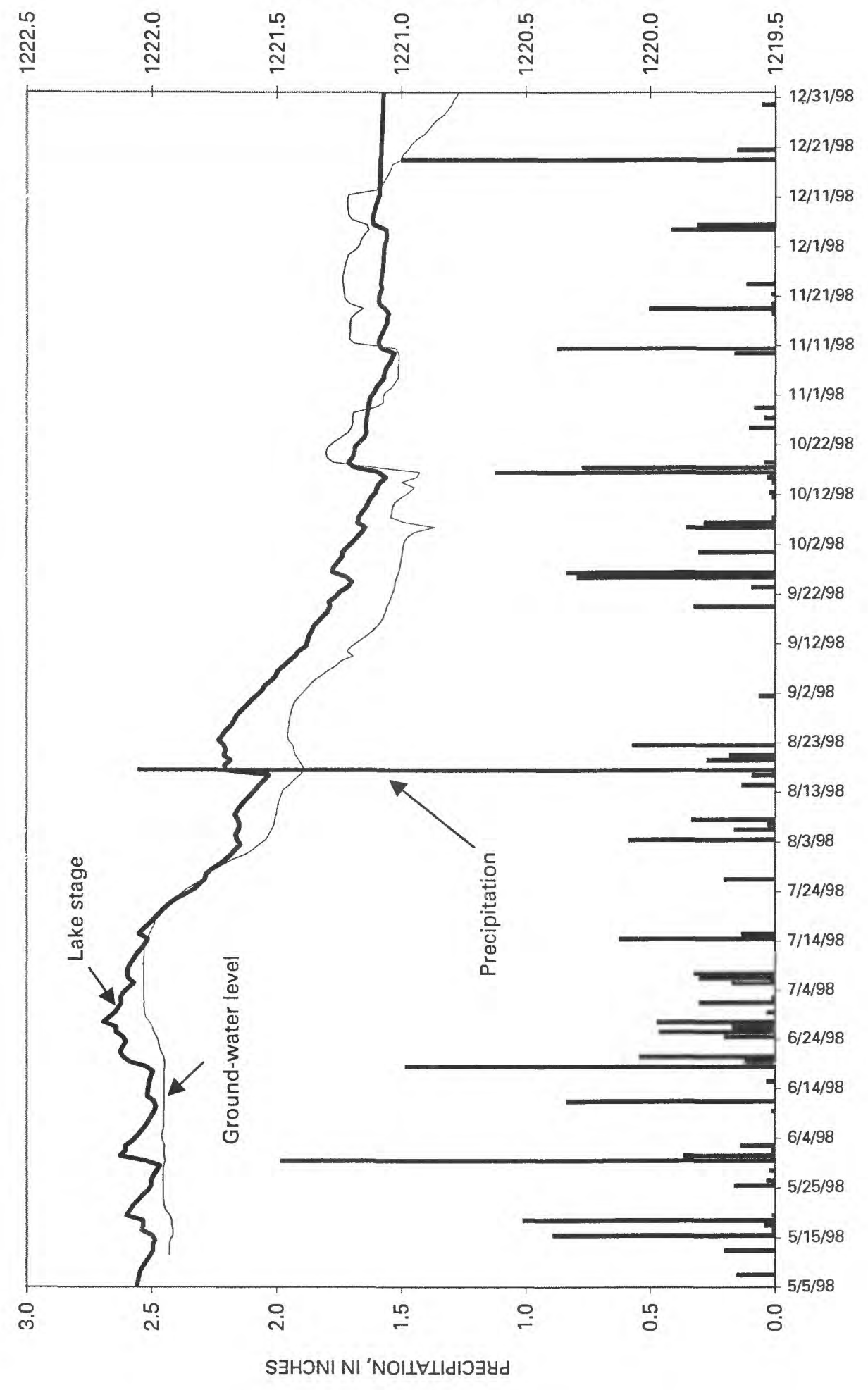

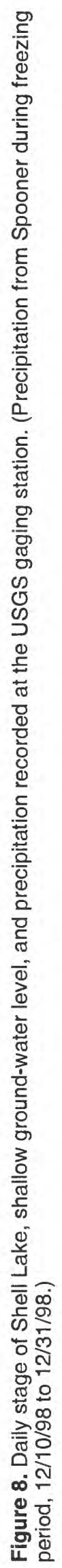




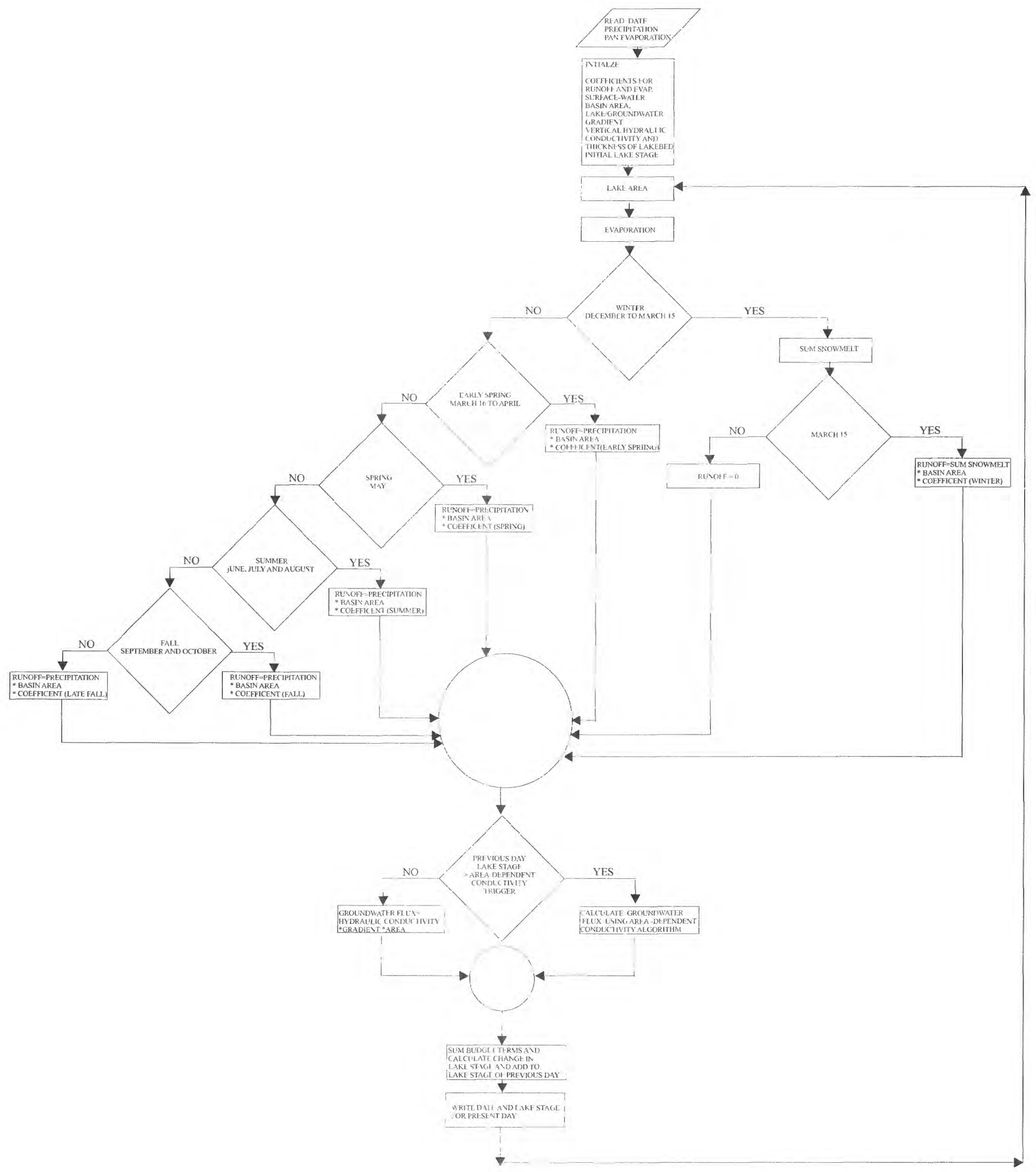

Figure 9. Program steps in hydrologic-budget model of Shell Lake, Wis. (Fortran code and equations are listed in the appendix.) 
model was first calibrated for the period July 3, 1948 to December 31, 1996 and then through 1998. UCODE (Poeter and Hill, 1998) was coupled to the water-budget model and automatically varied runoff coefficients over a reasonable range until the differences between measured daily lake stage and model-calculated lake stage were minimized. This difference is called the calibration error.

For the 1948-96 calibration period, the six seasonal runoff coefficients were optimized repeatedly for a series of vertical hydraulic conductivity $(\mathrm{Kz})$ values. (The runoff coefficients and the $\mathrm{Kz}$ value cannot be optimized together because they are too closely correlated in their effect on the calibration error.) The range of $\mathrm{Kz}$ values used was 0.010 to $0.025 \mathrm{ft} / \mathrm{day}$. The model run with the lowest root mean square error $(0.59 \mathrm{ft})$ corresponds to a model run with a $\mathrm{Kz}$ value of $0.020 \mathrm{ft} /$ day. The optimized runoff coefficients for this $\mathrm{Kz}$ value together with the assumed value of zero runoff for the winter months yield a global runoff coefficient for the entire year equal to 0.168 (that is, the model predicts that on average 16.8 percent of the precipitation on the basin flows into the lake).

When the model was extended into the second calibration period - from 1996 to 1998 - the optimized runoff coefficients and the $\mathrm{Kz}$ value of $0.02 \mathrm{ft} /$ day produced lake stages that were about $2 \mathrm{ft}$ higher than the measured stages. These parameters also predicted excessive lake stages for earlier periods, when large differences between precipitation and evaporation produced high lake stages. Given the tendency of the waterbudget model to over predict high lake stages, it was clear that it needed to be refined. A physical mechanism that would correct the bias of the model predictions is a "self-limiting" process at high water levels. The presence of high permeability, sandy deposits along the fringe of the lake (especially on its northern side) provides this mechanism. The data suggest that at high water levels the lake loses water at a higher rate by percolation to ground water through the fringe than it does through its normal lakebed.

A new function controlled by the area-dependent conductivity factor (ADCF) was employed to account for the effect of the fringe. The ADCF factor is applied to the $\mathrm{Kz}$ value of the fringe above a defined lake stage, or threshold. The fringe area is defined as the total area of the lake less the area of the lake at the threshold stage. For the calibrated model, the area-dependent conductivity threshold (ADCT) is 1,221 ft. At lake stages greater than $1,221 \mathrm{ft}$, the $\mathrm{Kz}$ value of the fringe area increases at an increasing rate (set by the ADCF factor) with the rise in lake stage. This "accelerating" effect is expected because with rising stage, the lake encroaches on increasingly sandy beach deposits. Given the assumed fixed downward vertical gradient of $0.20 \mathrm{ft} / \mathrm{ft}$, Darcy's Law implies that the flux out of the fringe area of the lake to the ground-water system also increases at an increasing rate with lake stage. This enhanced percolation from the fringe limits the rate at which the lake rises when precipitation greatly exceeds evaporation (that is, when lake levels rise above the ADCT).

It seems reasonable that as lake stage increases above the ADCT, areas not normally subjected to lake sedimentation become inundated. These inundated areas would have a higher vertical hydraulic conductivity than the average for the lakebed because finegrained lake sediment is absent. The algorithm for the ADCF is included in the FORTRAN code contained in appendix 1 .

The "best fit" or calibration between measured and model-calculated lake stages for the entire period of record occurs with runoff coefficients of 0.83 for snowmelt during the major thaw, 0.14 for rainfall in early spring, 0.27 for rainfall in spring, 0.03 for rainfall in summer, 0.14 for rainfall in fall and 0.02 for rainfall in late fall, a vertical hydraulic conductivity of the lake bed of $0.02 \mathrm{ft} /$ day and an area-dependent conductivity factor of 214 . The ADCF value equal to 214 yields a fringe $\mathrm{Kz}$ value of $5.35 \mathrm{ft} /$ day at a stage of $1,222 \mathrm{ft}, 1 \mathrm{ft}$ above the ADCT. At this high stage, the fringe represents 1.4 percent of the total lake area. Because the normal $\mathrm{Kz}$ value of $0.02 \mathrm{ft} /$ day represents the remaining 98.6 percent of the lake bottom, the average $\mathrm{Kz}$ for the entire lake is $0.08 \mathrm{ft} /$ day. This elevated overall $\mathrm{Kz}$ value (four times the normal value) implies that at the $1,222 \mathrm{ft}$ stage, the lake will lose to ground water at about three times the rate it loses at the $1,221 \mathrm{ft}$ stage. Consequently, the rise in lake stage predicted by the model is less than it would be if the fringe were not active.

Parameters not varied during the calibration process include the hydraulic gradient between the lake and shallow ground-water system $(-0.20)$ and the pan evaporation coefficient of 0.80 .

The average amount of precipitation and the subsequent runoff that occurs during each runoff period vary. The percentage of average annual precipitation observed for the runoff periods are: (1) 10.1 percent for winter (December through March 15), (2) 10.2 percent for early spring (March 16-April), (3) 11.3 percent for spring (May), (4) 42.5 percent for summer (June, July, 
and August), (5) 20.2 percent for fall (September and October), (6) 5.5 percent for late fall (November) and 0.2 percent on March 15. Based on the calibrated runoff coefficients, it is interesting to note that even though 42.5 percent of the average annual precipitation falls in the summer, the model predicts that only 3 percent or 0.37 in. $(0.425 \times 29.3$ in. X 0.03$)$ of runoff is contributed to the lake during the summer. In contrast, during an average winter, when only 10.1 percent of the annual precipitation falls, 2.33 in. of runoff occurs $(0.101 \mathrm{X}$ 29.3 in. X 0.79). This underscores the effect of the temporal variation of precipitation on lake stage. For example, two years may have the same amount of precipitation but may have very different changes in lake stage. In a year with a large amount of snowfall there will be a large increase in lake stage compared to a year with a small amount of snowfall.

Figure 10 shows the "best-fit" match between the observed and simulated lake levels for Shell Lake over the period of record. The root mean square error for this optimal simulation is $0.54 \mathrm{ft}$.

Inspection of figure 10 shows that trends in model calculated lake stage compare reasonably well with historical lake stage trends for Shell Lake. Long-term trends in the measured stage of Shell Lake starting in 1948 indicate three cycles of low to high lake stage that are simulated by the calibrated model. Low lake stages occur in 1949 (1214.96 ft above sea level), 1965 $(1,215.76 \mathrm{ft}$ above sea level), and $1977(1,216.44 \mathrm{ft}$ above sea level) while high stages occur in 1954 $(1,221.01 \mathrm{ft}$ above sea level), $1969(1,220.4 \mathrm{ft}$ above sea level), and 1986 (1,221.99 ft above sea level). Since 1986, lake stage has been between 1,218.63 and $1,222.69 \mathrm{ft}$ above sea level, the highest stage for the period of record.

The measured daily lake stage, however, does not always compare well with the simulated daily lake stage. Reasons for this are in all of the assumptions and necessary simplifications discussed above. The most critical assumption seems to be that average runoff coefficients can be used to calculate daily runoff to the lake. Average runoff coefficients do not always accurately predict daily runoff. Runoff can be greatly affected by antecedent moisture conditions and evapotranspiration, both of which can vary daily.

Another assumption used is that the gradient between the lake and ground water is constant. Temporal and spatial variations in gradients occur (fig. $7 \mathrm{a}$ and $7 \mathrm{~b}$ and fig. 8). Even though it appears that the average gradient does not vary much, a variable ground- water gradient may be necessary for highly accurate simulation of daily ground-water flow.

\section{APPLICATION OF MODEL TO PREDICTION OF LAKE STAGE}

The calibrated water-budget model was used to predict the effect of reducing runoff or withdrawing water on lake stage. The predictive simulations were run using the climate data (daily precipitation and evaporation) for the calibration period (1948 to 1998).

Simulated daily lake stages using runoff coefficients reduced by 5 percent were compared to the calibrated-modeled lake stages. A reduction in runoff coefficients by 5 percent might occur if, for example, one or more of the tributary streams were dammed or had control structures installed. This comparison indicated that during periods of low lake stage, the reduced coefficients cause lake levels to drop about 1 foot. During the period of high lake stage in the late 1990's, however, the reduced runoff coefficients had little or no effect on lake stage. The reason for this is that the fringe effect that efficiently "rids" the lake of water at high stages is weakened in the presence of the limits on lake stage imposed by runoff control. In essence, the gains in controlling lake stage produced by runoff control are negated by the loss of the fringe effect.

A second set of predictive model runs was made to simulate the effect of withdrawing water from the lake by pumping or siphoning as the U.S. Army Corps of Engineers (1988) suggests. For these runs, it was assumed that water was withdrawn when a lake stage of 1,220 feet above sea level was exceeded. Based on the area calculated for a lake stage of 1,220 feet above sea level, it would take approximately 1.5 years of pumping at $1,000 \mathrm{gpm}(2.2 \mathrm{cfs})$ to lower the lake stage $1 \mathrm{foot}$. Pumping rates of 1,000 and 2,000 gpm were simulated.

Results of these predictive simulations indicate that pumping may be an effective way to lower lake stage (fig. 11). During periods of high lake stage, simulated pumping at 2,000 gpm reduces lake stage about 1 foot and slightly less than 1 foot during periods of low stage. The predicted average lake stage reduction during the late 1990's high stage period if pumping at 2,000 gpm was $1.17 \mathrm{ft}$., and was $0.83 \mathrm{ft}$ if pumping at $1,000 \mathrm{gpm}$. Model results indicate that for the case of pumping at $1,000 \mathrm{gpm}$ with a trigger of $1,220 \mathrm{ft}$, it is expected that about 15 percent of the years will require considerable pumping and that generally more than 200 days of pumping occur in those years needing pumping. 


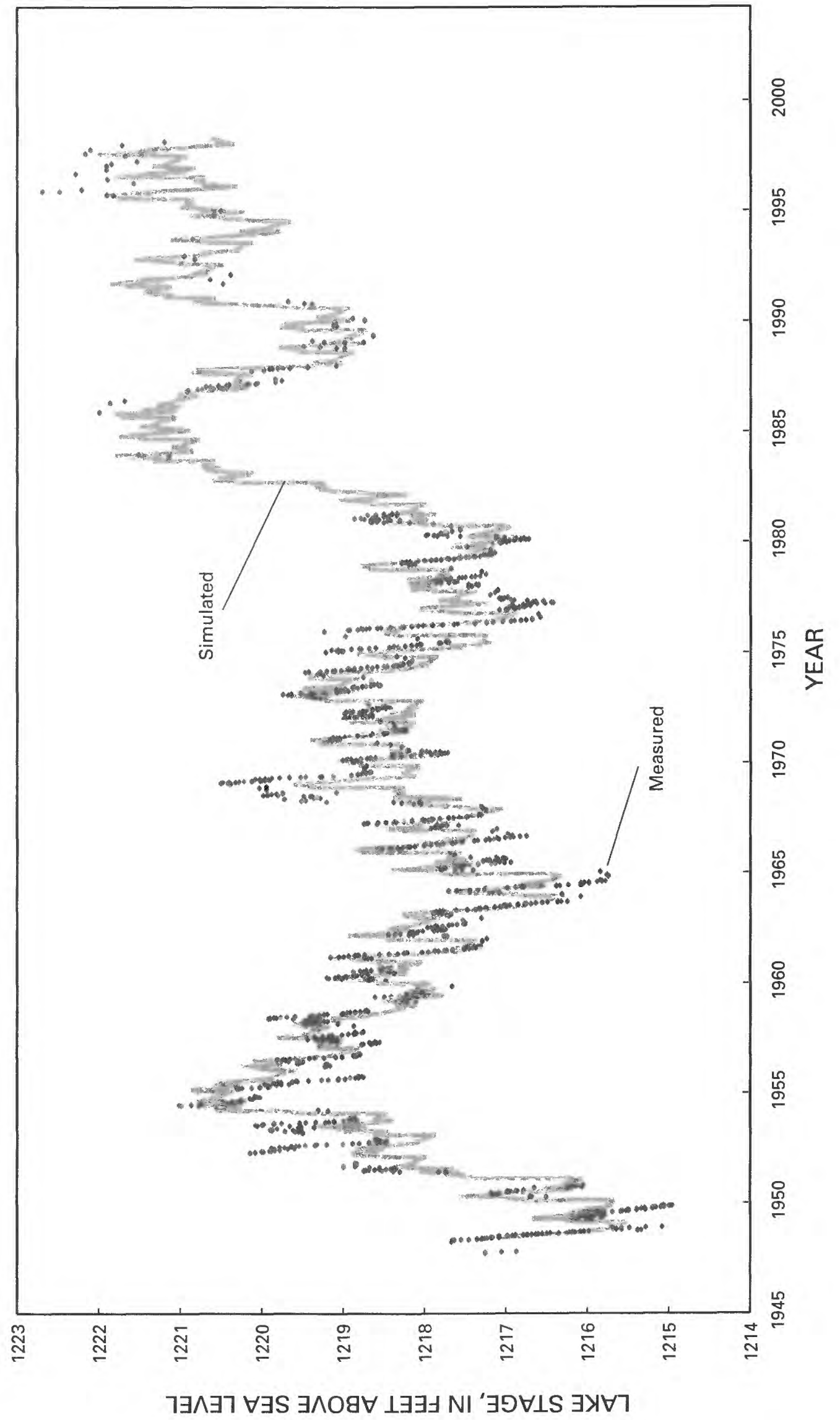

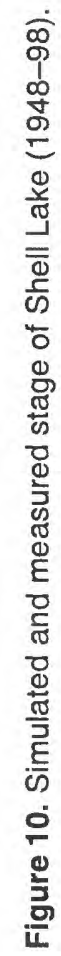




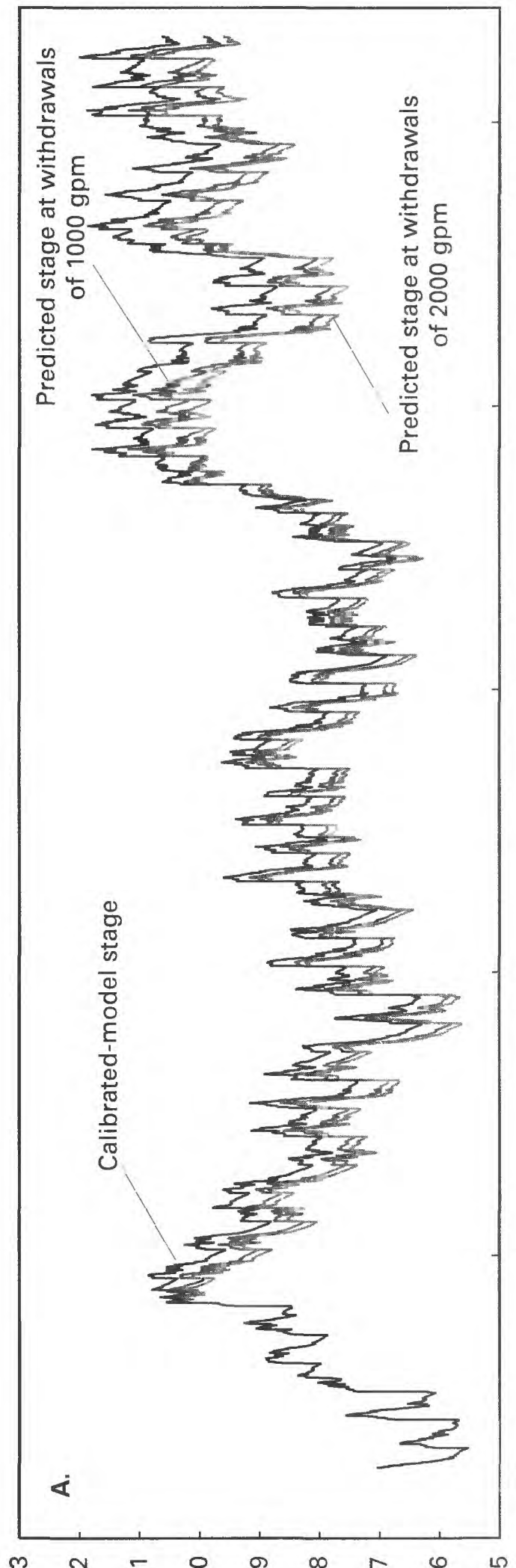

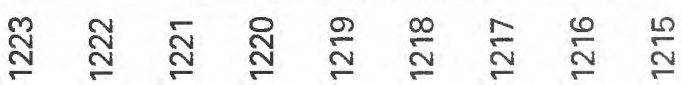

\urcorner$\exists \wedge \exists า \forall \exists S \exists \wedge O 8 \forall \perp \exists \exists \unlhd$ NI ' $\exists \supset \forall \perp S \exists \forall \forall\urcorner$

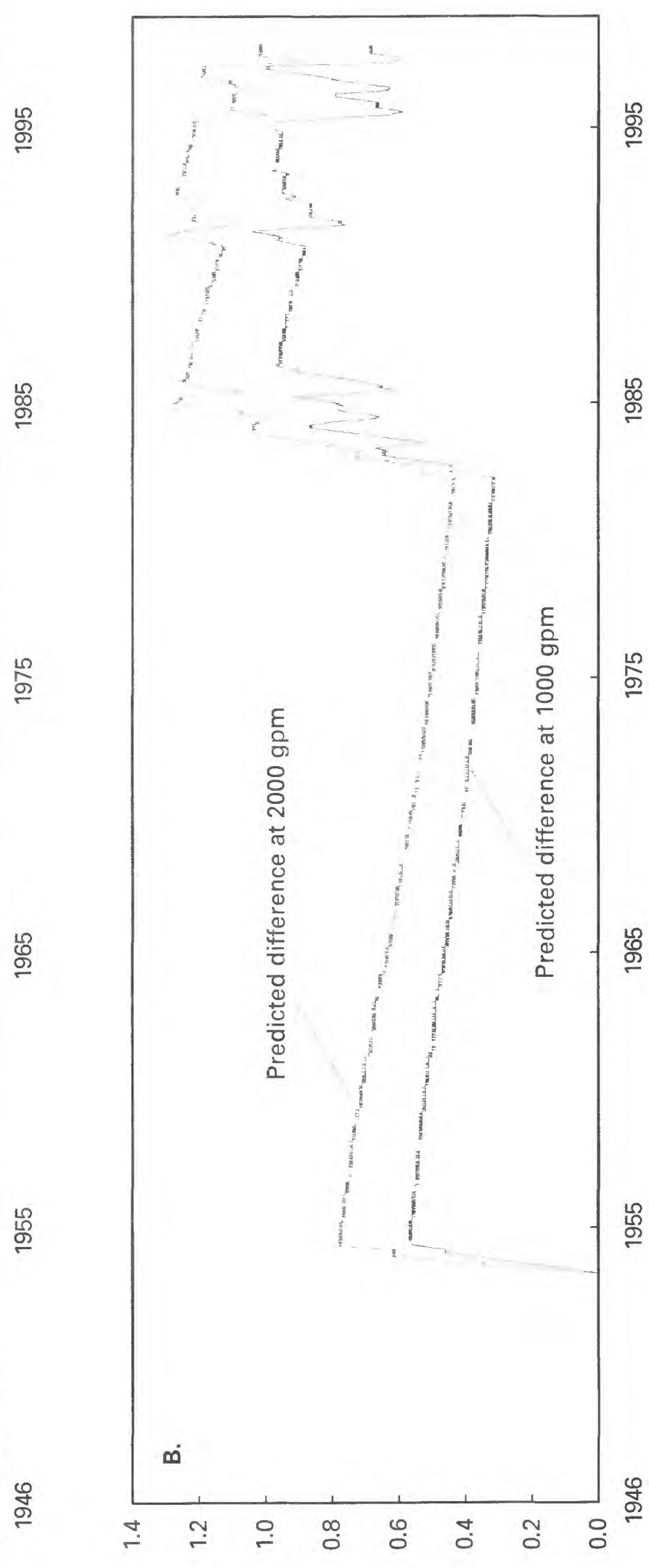

$\perp \exists \exists \exists \mathrm{NI}$

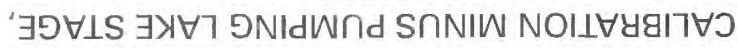

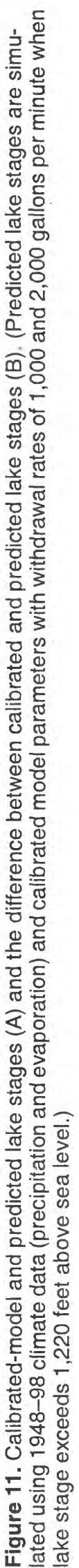




\section{SUMMARY AND CONCLUSION}

Withdrawal of lake water from Shell Lake has been considered because of recent flooding of near-shore residences. A better understanding of the hydrology of the lake and the long-term effects of withdrawing lake water on stage were required for water resource planners to make an informed decision. To meet these needs a study was done with these objectives: (1) to determine the hydraulic parameters and water-budget components of Shell Lake, (2) to simulate lake stage using estimated water-budget components, and (3) to provide a tool for prediction of lake stages.

A water-budget model was developed for Shell Lake. The model simulates daily lake stage by summing water-budget components, that is, precipitation, evaporation, runoff and ground-water flow. Daily precipitation from the Spooner and pan evaporation from the Marshfield Experimental Farm and Minocqua Airport were used as model input. Daily runoff was estimated by multiplying a three-day moving average of precipitation by drainage area and by a runoff coefficient. Runoff coefficients for six runoff periods within a year were estimated using the parameter estimation model UCODE. Ground-water flow was calculated using Darcy's Law. Vertical hydraulic conductivity was estimated by trial and error calibration and an average hydraulic gradient between the lake and the groundwater system was estimated during two piezometer surveys. An additional function, an area-dependent conductivity factor (ADCF), was needed to match the measured water levels periods of high stage.

The stage of Shell Lake has been measured intermittently for the past 51 years. These measurements were compared to model-calculated lake stages to calibrate the water-budget model. The calibrated model was then used in predictive simulations to indicate that reducing runoff by 5 percent would have had little effect on reducing lake stages during the 1990's high stage period. Withdrawing lake water appears to be an effective way of reducing lake stage. To lower lake stage by about 1 foot for conditions similar to the 1990's high water period would require several years of pumping for at least 200 days per year at a rate of 1,000 to 2,000 gpm. Reductions in lake stage that would result from withdrawing water at high stage would have the not necessarily desired effect of depressing lake levels during subsequent low-stage periods.

\section{REFERENCES CITED}

Krohelski, J.T., and Batten, W.G., 1995, Simulation of stage and the hydrologic budget of Devils Lake, Sauk County, Wisconsin: U.S. Geological Survey Open-File Report 94-348, $22 \mathrm{p}$.

Krug, W.R., Ostenso, N.A., and Krohelski, J.T., 1987, Prediction of the effects of mine dewatering on four lakes near Crandon, Wisconsin, by use of a water-budget model: U.S. Geological Survey Open-File Report 87-471, 63 p.

McBride, M.S., and Pfannkuch, H.O., 1975, The distribution of seepage within lakebeds: U.S. Geological Survey Journal of Research, v. 3, no. 5, p. 505-512.

Novitzki, R.P., 1982, Hydrology of Wisconsin wetlands: Wisconsin Geological and Natural History Survey Information Circular Number 40, 22 p.

Poeter, E.P., and Hill, M.C., 1998, Documentation of UCODE, a computer code for universal inverse modeling: U.S. Geological Survey Water-Resources Investigation Report 98-4080, 116 p.

U.S. Army Corps of Engineers, 1988, Draft Reconnaissance Report-Flood Control - Section 205-Shell Lake, Wisconsin: U.S. Army Corps of Engineers, St. Paul District, $31 \mathrm{p}$.

Wentz, D.A., and Rose, W.J., 1991, Hydrology of Lakes Clara and Vandercook in north-central Wisconsin: U.S. Geological Survey Water-Resources Investigation Report 89-4204, 24 p.

Wisconsin Department of Natural Resources, 1995, Wisconsin Lakes, PUB-FM-800 95REV, 182 p.

Wisconsin Department of Natural Resources, 1982, Shell Lake, Washburn County-Feasibility study results; management alternatives: Wisconsin Department of Natural Resources, Office of Inland Lake Renewal, 45 p. 


\section{APPENDIX}




\section{Appendix - Fortran program code used to simulate changes in stage of Shell Lake caused by}

\section{variations in hydrologic-budget components.}

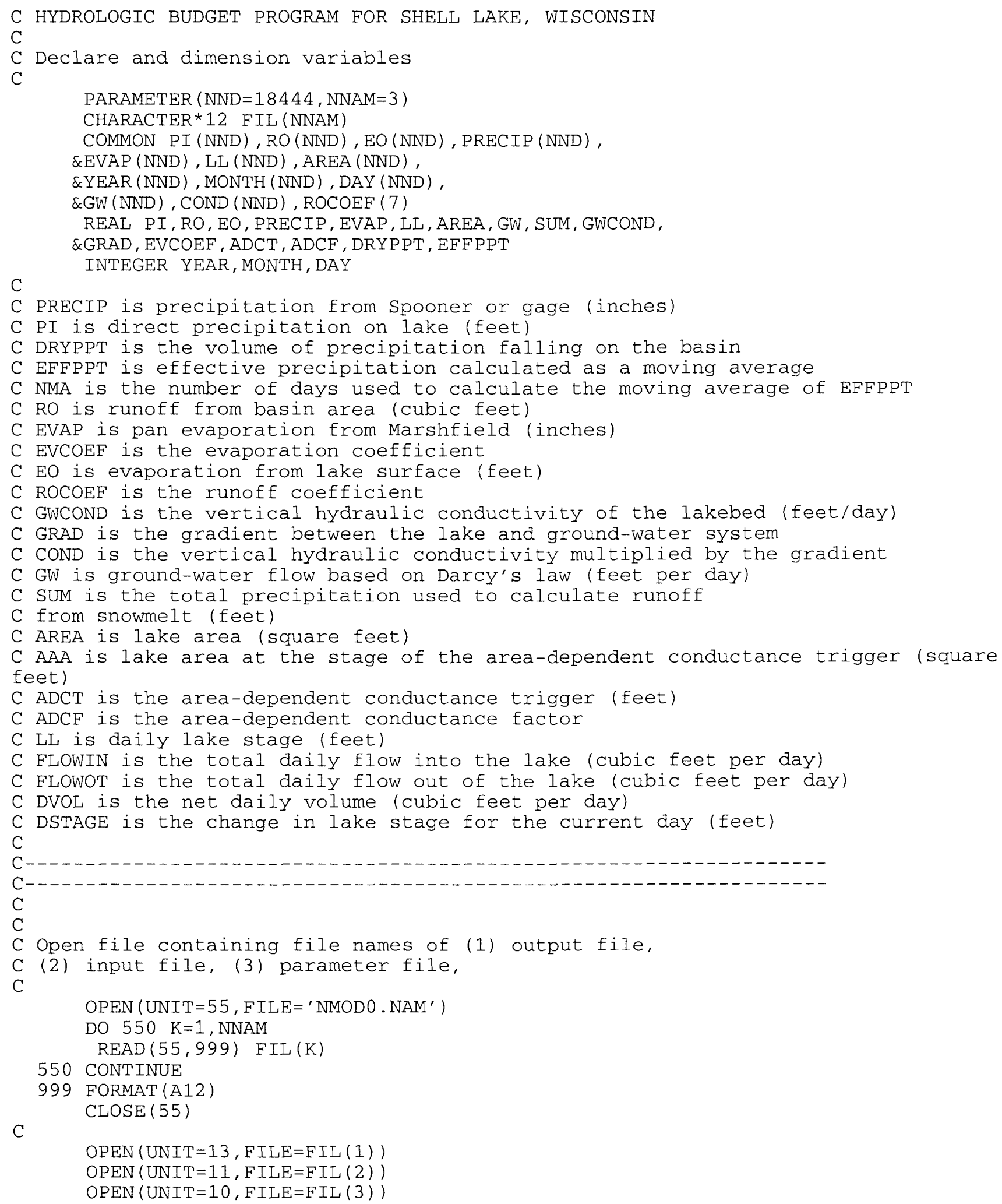


$\mathrm{C}$

$C$ Read in date and daily precipitation and evaporation in inches

$\mathrm{C}$

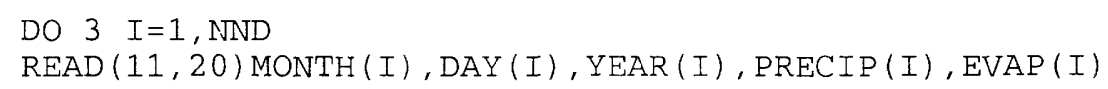

$\mathrm{C}$

20 FORMAT ( $2 X, I 2,1 X, I 2,1 X, I 4,2 F 10.2)$

$\mathrm{C}$

C Initialize sum of snowmelt

$\mathrm{C}$

SUM $=0.0$

$\mathrm{C}$

C READ RUNOFF COEFFICIENTS

C

DO $4 \quad I=1,7$

$\operatorname{READ}(10,26) \operatorname{ROCOEF}(I)$

4 CONTINUE

26 FORMAT (F10.5)

$\mathrm{C}$

C Read vertical hydraulic conductivity

C

$\operatorname{READ}(10,901)$ GWCOND

C

C Read lake/ground-water gradient

C

$\operatorname{READ}(10,901) \quad$ GRAD

$\mathrm{C}$

C Read pan evaporation coefficient

$\mathrm{C}$

C

$\operatorname{READ}(10,901) \quad$ EVCOEF

$C$ Read number of days for moving average

C

$\operatorname{READ}(10,905) \quad N M A$

C

C Read value for Area-Dependent Conductance Trigger

$\mathrm{C}$

$\operatorname{READ}(10,1906) \quad A D C T$

$\mathrm{C}$

C Read value for Area-Dependent Conductance Factor

$\mathrm{C}$

$\mathrm{C}$

$\operatorname{READ}(10,1906) \quad \mathrm{ADCF}$

901 FORMAT (F10.5)

905 FORMAT (I10)

1906 FORMAT (F10.2)

$\mathrm{C}$

C DA is BASIN AREA-LAKE AREA

C

$\mathrm{DA}=3.7892 \mathrm{e} 8$

$\mathrm{C}$

C Initialize lake level

C

$\operatorname{LL}(1)=1217.08$

$\mathrm{C}$

C Start loop to calculate daily lake stage

C

DO $9 I=1, N N D$

$\mathrm{C}$

C Calculate lake area in square feet

$\mathrm{C}$

$\operatorname{AREA}(I)=-1890921920.41+(1643379.95 * L L(I))$ 
$\mathrm{C}$

C Calculate lake area at the Area-Dependent Conductance Trigger

$\mathrm{C}$

$$
\mathrm{AAA}=-1890921920.41+(1643379.95 * \mathrm{ADCT})
$$

$\mathrm{C}$

C Calculate precipitation in feet

$\mathrm{C}$ $\operatorname{PI}(I)=\operatorname{PRECIP}(I) / 12$

$D R Y P P T=D R Y P P T+P I(I) * D A$

C

C Sum precipitation for snowmelt

C

$S U M=S U M+P I(I)$

$\mathrm{C}$

C Calculate effective precipitation rate for runoff calculation

$\mathrm{C}$ assuming 3 -day moving average including current day

$\mathrm{C}$

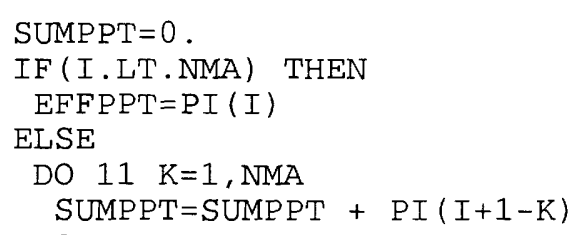

$\mathrm{C}$

C Calculate evaporation in feet

$\mathrm{C}$

C

$\operatorname{EO}(I)=(\operatorname{EVAP}(I) / 12) * \operatorname{EVCOEF}$

C Calculate runoff in cubic feet

C

C

C Runoff for December, January and, February

C

IF (MONTH (I) . GT . 11. OR.MONTH (I) . LT. 3) THEN

$\mathrm{RO}(I)=\mathrm{EFFPPT} * \mathrm{DA} * \mathrm{ROCOEF}(7)$

END IF

IF (MONTH (I) . GT . 11. OR. MONTH (I) . LT. 3) THEN

SUM $=$ SUM-ROCOEF $(7)$ *EFFPPT

ENDIF

$\mathrm{C}$

C Runoff for March 1-15

C

IF (MONTH (I) .EQ . 3.AND.DAY (I) .LT. 16) THEN

$R O(I)=E F F P P T * D A * R O C O E F(7)$

END IF

IF (MONTH (I) .EQ . 3.AND.DAY (I) .LT. 16) THEN

ENDIF

SUM $=$ SUM-ROCOEF $(7)$ *EFFPPT

$\mathrm{C}$

C Runoff for March (days greater then 15) and April

C

IF (MONTH (I) .EQ. 3.AND.DAY (I) .GT.15 .OR. MONTH(I) .EQ.4) THEN $\mathrm{RO}(I)=\mathrm{EFFPPT} * \mathrm{DA} * \mathrm{ROCOEF}(1)$

END IF

$\mathrm{C}$

C Runoff for May

C

IF (MONTH (I) .EQ.5) THEN

$\mathrm{RO}(I)=\mathrm{EFFPPT} * \mathrm{DA} * \mathrm{ROCOEF}(2)$

C

END IF 
C Runoff for June, July and August

C

IF (MONTH ( I ) . GT . 5. AND.MONTH (I) . LT . 9) THEN $R O(I)=E F F P P T * D A * R O C O E F(3)$

END IF

$\mathrm{C}$

C Runoff for September and October

C

IF (MONTH ( I ) . GT . 8.AND. MONTH (I) . LT . 11) THEN $\mathrm{RO}(I)=\mathrm{EFFPPT} * \mathrm{DA} * \mathrm{ROCOEF}(4)$

END IF

C

C Runoff for November

C

IF (MONTH (I) .EQ.11) THEN

$\mathrm{RO}(\mathrm{I})=\mathrm{EFFPPT} * \mathrm{DA} * \mathrm{ROCOEF}(5)$

END IF

$\mathrm{C}$

C Runoff from snowmelt (March 15)

C

IF (MONTH (I) .EQ.3 .AND.DAY (I) .EQ.15) THEN $\mathrm{RO}(I)=\mathrm{SUM} * \mathrm{DA} * \mathrm{ROCOEF}(6)$

END IF

C

IF (MONTH (I) .EQ.11.AND.DAY (I) .EQ.30) THEN

$S U M=0.0$

C

END IF

C Calculate ground-water flow from lake

$\mathrm{C}$

$\mathrm{GW}(I)=\mathrm{GWCOND}{ }^{*} \mathrm{GRAD}$

$\operatorname{COND}(I)=$ GWCOND

IF ( LL (I) . GT . ADCT) THEN

$F A C T=L L(I)-A D C T$

$\mathrm{FACT}=\mathrm{FACT} * \mathrm{ADCF}$

$F C O N D=G W C O N D+G W C O N D * F A C T$

FAREA $=$ AREA (I) -AAA

$\operatorname{COND}(I)=($ AAA $/$ AREA $(I)){ }^{*}$ GWCOND + (FAREA /AREA (I ) $) *$ FCOND

ENDIF $\mathrm{GW}(I)=\mathrm{COND}(I){ }^{*} \mathrm{GRAD}$

C

C Water balance and lake level calculations

$\mathrm{C}$

FLOWIN $=R O(I)+P I(I) * A R E A(I)$

FLOWOT $=E O(I) * A R E A(I)+G W(I) * A R E A(I)$

DVOL $=$ FLOWIN - FLOWOT

DSTAGE $=$ DVOL $/$ AREA $(I)$

$\mathrm{C}$

$\mathrm{LL}(I+1)=\mathrm{LL}(I)+\mathrm{DSTAGE}$

C

C

9 CONTINUE

C Write date and lake level

C

DO $45 \mathrm{I}=1$, NND

WRITE $(13,21) \operatorname{MONTH}(I), \operatorname{DAY}(I), \operatorname{YEAR}(I), \operatorname{LL}(I)$

21 FORMAT (I2,' ',',I2,' ', , I4 , 2X, F8 . 2)

$\mathrm{C}$

45 CONTINUE

C Program end

C

STOP

END 
(4) Printed on recycled paper 